\title{
ArcheoSciences
}

Revue d'archéométrie

$31 \mid 2007$

Varia

\section{Impact of charcoal production activities on soil profiles: the micromorphological point of view}

Impact de la production de charbon sur le sol forestier :apport de la micromorphologie des sols

\section{Anne Gebhardt}

\section{OpenEdition}

Journals

Édition électronique

URL : https://journals.openedition.org/archeosciences/833

DOI : 10.4000/archeosciences.833

ISBN : 978-2-7535-1596-3

ISSN : 2104-3728

Éditeur

Presses universitaires de Rennes

\section{Édition imprimée}

Date de publication : 31 décembre 2007

Pagination : 127-136

ISBN : 978-2-7535-0618-3

ISSN : $1960-1360$

\section{Référence électronique}

Anne Gebhardt, «Impact of charcoal production activities on soil profiles: the micromorphological point of view », ArcheoSciences [En ligne], 31 | 2007, mis en ligne le 31 décembre 2009, consulté le 01 février 2022. URL : http://journals.openedition.org/archeosciences/833 ; DOI : https://doi.org/ 10.4000/archeosciences.833 


\title{
Impact of charcoal production activities on soil profiles: the micromorphological point of view
}

\author{
Impact de la production de charbon sur le sol forestier : \\ apport de la micromorphologie des sols
}

\author{
Anne Gebhardt*
}

\begin{abstract}
The aim of this research is to understand better the impact of the traditional charcoal production on the soil. The focus is on the soil micromorphological study of several profiles located under ancient and recent charcoal mounds: the Paimpont forest (Ille-et-Vilaine, France), the Zonien forest (Belgium) and at the Écomusée de Haute-Alsace (Ungersheim, France). The experimental burning of a silt-loamy profile completed this task.

The collected data indicate that the impact of charcoal exploitation on the soil micromorphology is not directly due to the combustion effects, but more to operations related to the local deforestation for wood exploitation, the preparation and management of the plots before, during and after the production phase and the domestic activities of the charcoal burners. The micromorphological study also allows tracing the origin of the turves that were used during the construction of the charcoal mound.

Résumé : Le but de cette recherche a été de comprendre l'impact de la production de charbon de bois sur le sol forestier. Ce travail a principalement consisté en une étude micromorphologique de plusieurs profils de sol, localisés sous des charbonnières anciennes et récentes : dans la forêt de Paimpont (Ille-et-Vilaine, France), en forêt de Soigne (Belgique) et à l'Écomusée de Haute-Alsace (Ungersheim, France). La combustion expérimentale de divers horizons d'un sol limono-silteux naturel vient compléter ce référentiel.

Les données obtenues montrent que l'impact du charbonnage sur la microstructure du sol n'est pas en relation directe avec la combustion de la meule, mais plutôt liée au mode de déforestation, de préparation, d'aménagement et d'entretien de l'aire de charbonnage tout au long des différentes phases de production, ainsi qu'aux activités domestiques du charbonnier. L'étude micromorphologique des sédiments à également permis mettre en évidence l'utilisation de mottes tourbeuses pour la construction de la meule.
\end{abstract}

Keywords: Belgium, Charcoal mound, Experimental archaeology, France, Soil micromorphology.

Mots clés : Belgique, charbonnière, Archéologie expérimentale, France, Micromorphologie des sols.

\section{INTRODUCTION}

Studying the landscape evolution under Human impact requires reference to numerous anthropic activities which influence, among others, vegetation and soils. Since people became sedentary, intentional pressure on the wood- land has become more and more strong as the need of land for cultivation or wood for domestic and artisan purposes increased.

One of these activities is charcoal burning, which was very intensive until the beginning of $20^{\text {th }}$ century. Apart from strong pressure on the vegetation, the question is here to

*UMR 7011, ULP Strasbourg, UMR 6566 CREAAH, université de Rennes1 - INRAP, 95, rue Henri Becquerel, 54710 Ludres. (anne.gebhardt-even@ inrap.fr) 
improve to check the impact of this charcoal production activity on the soil.

To enlarge this knowledge and to make interpretations more reliable, it is also common practice to turn to experimental case studies. Fortunately, in the frame of the traditional charcoal production, which locally was still in practice in the mid-twentieth century, such operations are still occasionally performed

After a quick description of the main steps of charcoal burning, this paper will focus on the soil micromorphological study of several profiles located under ancient and recent charcoal mounds. The experimental burning of a loam profile at Gent University Laboratory of Micropedology completed this task.

\section{Material AND METHODS}

We had the opportunity to study the three following plots.

\section{The Paimpont Forest (Ille-et-Vilaine, France)}

Archaeological investigation of an ancient charcoal mound was done in 1993 in the Paimpont forest, on the Armorican Sandstone substrate, near the village of Hucheloup. Intensive charcoal activity existed here in the past. The studied mound was chosen for its location on a gentle slope, and for its thickness of about $30 \mathrm{~cm}$ which made a specific preparation of the plot most likely (Hunot, 1993, unpublished field notes).

The charcoal mound was about $8 \mathrm{~m}$ in diameter and the section shows 3 layers rich in charcoal, separated by a thin clay layer of 1 to $3 \mathrm{~cm}$ thick, probably excavated from some local marschy areas (Fig. 1. The dark layers are shifted one to each other toward the west, indicating reorganisation of the plot for each of the 3 successive uses. The charcoal remnants were studied by J.-Y. Hunot and D. Marguerie [Gebhardt et al., 1995]).

The soil micromorphological study concerned the evolution of the anthropic topsoil horizon since abandonment (start of the pedogenesis, integration and alteration of charcoal in the soil, P1) compared to the natural organic surface horizon nearby (A0/1 horizon, P2 - see Fig. 1).

\section{The Zonien Forest (Belgium)}

Mees (1989) made an archaeo-pedological mapping of a site with traces of $7^{\text {th }} / 9^{\text {th }}$ century metallurgic activity in the
Zonien Forest (Belgium). This provided the opportunity to study an ancient charcoal production plot, most probably associated with this activity (Langohr, personal communication, 2003). The charcoal mount profile description (CM) compared to the original local reference loess forest soil (R) is given in Fig. 1, together with some analytical data (Table 2; Mees, 1989).

The micromorphological investigations done by Mees were completed and standardised here in order to allow a better comparison between the different case studies presented in this paper.

\section{The Écomusée de Haute-Alsace (Ungersheim, France)}

In October 1995, the Ecomusée de Haute Alsace gave us the opportunity to study a demonstration charcoal exploitation plot, organized for the public. Traditional charcoal was made here in the ancient way. The demonstration was carried out in the Ill river alluvial forest, which has never been cultivated.

So we had the opportunity to compare some undisturbed soil blocks sampled under 2 charcoal burning plots, one used once (profile 1T) and another used 4 times (profile 4T) to the natural soil profile (profile Ref; Fig. 1).

\section{The laboratory heating experiment of soil samples (Belgium)}

In 1993, while holding a 'Human and Capital Mobility' postdoctoral contract from the EEC at the International Training Centre of the University of Gent, Belgium, some laboratory experiments where done in order to study by micromorphological observations the impact of soil heating. Thus different depth horizons of a loess profile (from the Zonien Forest, Belgium) were heated in a laboratory oven at $200^{\circ} \mathrm{C}, 400^{\circ} \mathrm{C}$ and $600^{\circ} \mathrm{C}$ (Table 3).

\section{Soil micromorphological descriptions and data presentation}

The micromorphological description follows the international terminology (Bullock et al., 1985). For the semi-quantitative counting, the thin sections are divided in $2 \mathrm{~cm}$ deep horizontal zones. Codes are chosen for each microfeature described (Fig. 4) and the results are tabulated to provide good comparison between the studied profiles. Observation is done under low magnification (obj. x4), except for some biogenic inclusions that can only be observed under high magnification (obj. x20). 


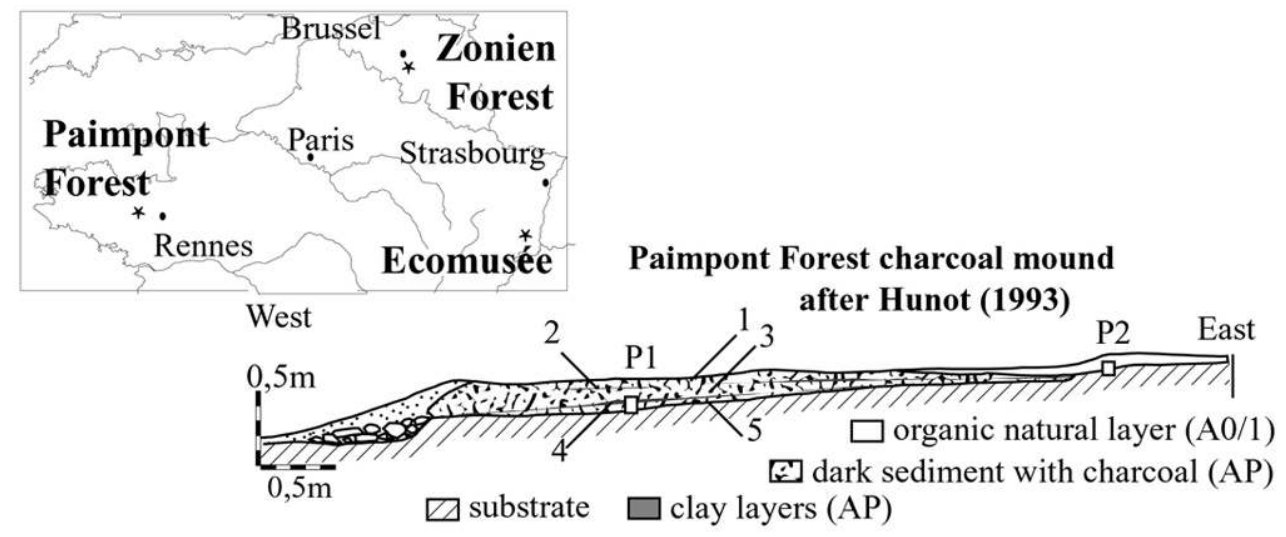

\section{Zonien Forest (Belgium) profiles after Mees (1989)}
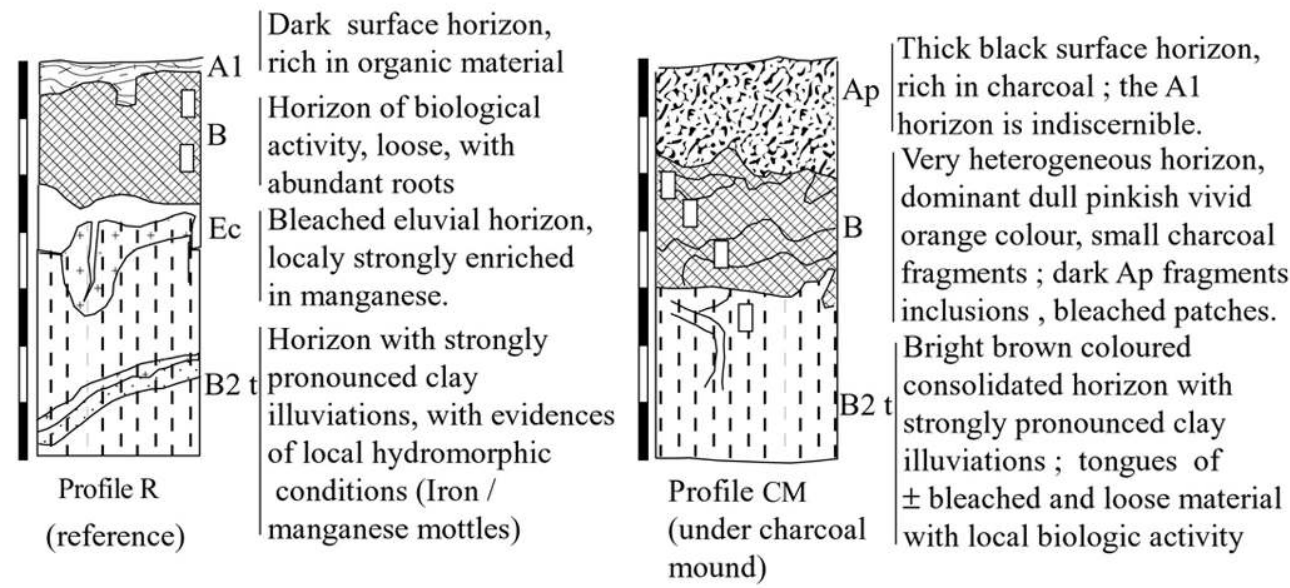

Ecomusée de Haute Alsace profiles

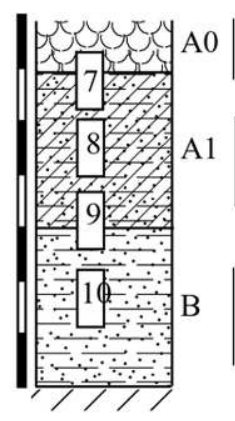

| Dark brown cloddy litter layer (leaf)

Brown-black sandy

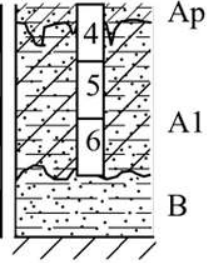

Brown black heterogeneous compact horizon.

A1 Clayey sandy brown grey horizon, numerous roots.

Clayey sandy yellowish-brown horizon. clay cloddy horizon, Under a charcoal stack used 1 time - profile 1T with a lot of roots.

Compacted, yellowish clayey sandy, with roots and biogalleries

Reference profile - profile Ref

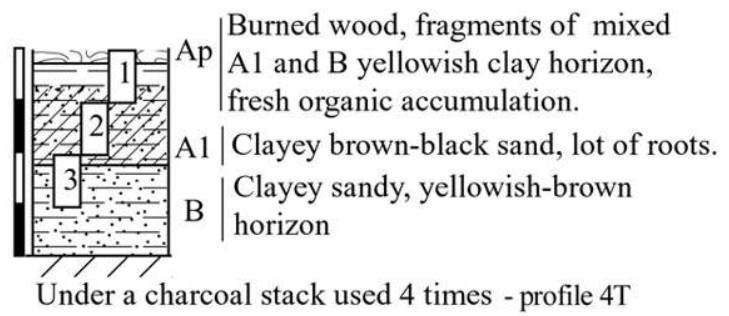

Figure 1: Location of the sites and soil profile descriptions from the Paimpont Forest (France) charcoal mound transect, the Zonien Forest (Belgium) described after Florias Mees (1989), and the Ecomusée de Haute Alsace (France). At the Paimpont Forest charcoal mound (after Hunot, 1993), the deepest charred layer (5) is 5,4m long, the middle one (3) 6,6m, the upper one (1) is 6,9m long. Bioturbations are observed mainly in the first $5 \mathrm{~cm}$; after $10 \mathrm{~cm}$ depth, biogalleries (roots, worms) become rare.

Figure 1 : Localisation des sites et description du profil de la meule de la forêt de Paimpont (France), de la forêt de Soigne (Belgique, d'après Florias Mees, 1989) et de l'Écomusée de Haute Alsace (France). En forêt de Paimpont, le niveau de combustion le plus profond (5) de la charbonnière fait 5,4 m de long, l'intermédiaire (3) fait 6,6 m et le supérieur (1) 6,9 m. Des bioturbations sont observées dans les premiers $5 \mathrm{~cm}$; au delà de $10 \mathrm{~cm}$ de profondeur, les biogaleries (racines, vers) deviennent rares. 


\section{Results}

\section{The traditional art of the charcoal-burner}

The preparation of the site (Fig. 2) is very important. It should be very flat, not too dry, not too wet (Larcher, 1986). Thus on slopes, terraces are build. It should be cleared of organic remains, and humus rich surface horizons are removed, sometimes down to $20 \mathrm{~cm}$ depth. Vegetation and roots should be deeply extracted with hoe, spade or a motocultor, depending on traditional or modern facilities (Grosz, pers. comm.).

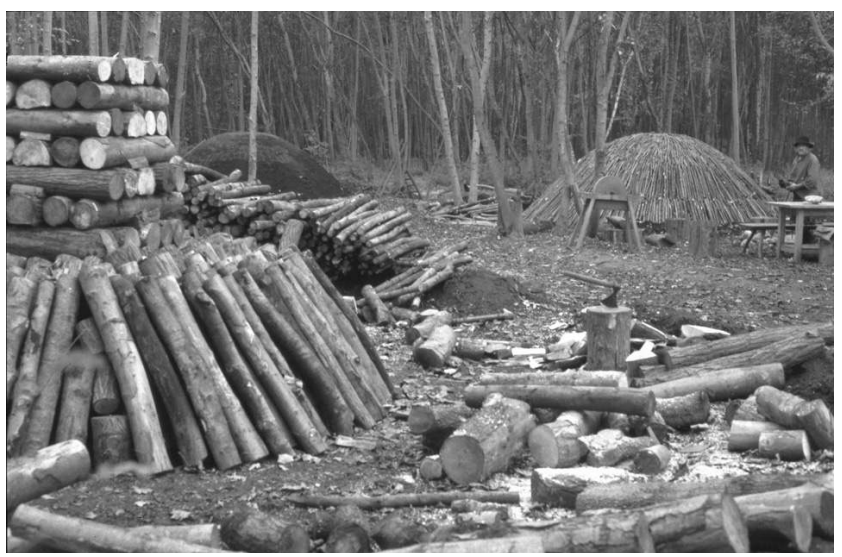

Figure 2: The different stages of construction of charcoal mounds at the Ecomusée de Haute Alsace (France).

Figure 2: Les différentes étapes de la construction d'une charbonnière à l'Écomusée de Haute-Alsace (France).

It is thus understandable that, when possible, the mound was rebuilt on an ancient, already prepared charcoal plot. Also, according to Larcher (1986), the production of charcoal increases by $10 \%$ on well prepared, already used soils. The colonisation by vegetation on ancient charcoal plots is very poor, which facilitates the reuse of the plot (Hunot, 1993, unpublished field notes).

While preparation the plot, the upper organic horizons are well mixed with lower mineral ones and kept apart for later use (Grosz, pers. com.). Turves are cut around the working area when available (Hunot, 1993), or imported from nearby grassland or natural pool banks (Bouflet and Lebreton, 1994).

A central chimney is build first. Then, to construct of the wood stack, the wood coppice logs are arranged around in a very precise way that mixes the size and the different tree species used in order to optimise the combustion (Fig. 2). When all the wood is set up, the stack is covered with the mixture of organo-mineral horizons and the turves (Larcher,
1986). The very finely crumby organo-mineral mixture covering the wood should penetrate into the smallest holes when the stack settles during the burning. This is to avoid oxidation and flame formation during combustion and the consequent compaction of the mound. This phase depends on the oxygenation rate and the quality of the combustion. The stack is then topped with fresh clay.

The combustion lasts about 5 (Larcher, 1986) to 10 days (Bouflet and Lebreton, 1994; Grosz, pers. com.). The temperature should reach around $530^{\circ} \mathrm{C}$ in the middle of the stack (Grosz, pers. com.), in order to obtain the best quality of charcoal (a lot of carbon, less gas; Table 1).

\begin{tabular}{|l|l|l|l|l|l|}
\hline & \multicolumn{4}{|l|}{ Percentage of material after combustion } \\
\hline & \multicolumn{4}{l}{ left in charcoal } & \multicolumn{2}{l|}{ gone with smoke } \\
\hline Temperature & Carbon & Gas & Ashes & Carbon & Gas \\
\hline $150^{\circ} \mathrm{C}$ & 47,51 & 52,41 & 0,08 & - & - \\
\hline $270{ }^{\circ} \mathrm{C}$ & 26,17 & 10,65 & 0,32 & 21,34 & 41,52 \\
\hline $350^{\circ} \mathrm{C}$ & 22,73 & 6,75 & 0,18 & 24,78 & 45,52 \\
\hline $1100^{\circ} \mathrm{C}$ & 15,32 & 2,86 & 0,22 & 32,19 & 49,41 \\
\hline $1500^{\circ} \mathrm{C}$ & 16,37 & 0,83 & 0,11 & 31,14 & 51,97 \\
\hline
\end{tabular}

Table 1: Variations of the quality of charcoal at different temperatures after 'La Grande Encyclopédie' from Marcelin Berthelot, 1885-1902 (in Larcher, 1986).

Tableau 1: Différences de qualités des charbons obtenus à différentes températures d'après La Grande Encyclopédie de Marcelin Berthelot, 1885-1902 (in Larcher, 1986).

The fire is lighted and the combustion is regularly maintained, in the beginning every 4 and later every 6 hours, by adding through the chimney, wood and/or bad quality charcoal from the previous combustion. Fresh pure clay is continuously added to cover the mound. This delicate and dangerous work is done from the top (Fig. 3).

At the base of the mound, ventilation holes allow air entrance for the combustion and facilitate the escape of smoke. In the last two days, the combustion is slowed down in reduced condition by closing these holes.

When the stack has considerably compacted and the turf burnt, the combustion reaches the external bottom edge of the mount (Larcher, 1986), but under the mound at the contact with the soil, the wood should not be completely burned (Grosz, personal communication, 1995). After cooling, the stack is opened, charcoal is raked, slightly broken, sorted and bagged for selling. The place is cleaned; the fine earth is sieved and reused for a next charcoal mound. 


\begin{tabular}{|l|l|l|l|l|l|l|l|l|l|l|l|l|l|l|l|}
\hline pro & $\mathrm{Hz}$ & depth & clay & silt & sand & & & & & \multicolumn{4}{|c|}{ exch. bases (meq/100g) } & & \\
\hline file & & $\mathrm{cm}$ & $\begin{array}{l}0- \\
2 \mu \mathrm{m}\end{array}$ & $\begin{array}{l}2- \\
50 \mu \mathrm{m}\end{array}$ & $\begin{array}{l}50- \\
2000 \mu \mathrm{m}\end{array}$ & $\mathrm{C} \%$ & $\mathrm{pH}$ & $\mathrm{Fe} \%$ & $\mathrm{Al} \%$ & $\mathrm{Ca}$ & $\mathrm{Mg}$ & $\mathrm{K}$ & $\mathrm{Na}$ & $\mathrm{CEC}$ & $\mathrm{V} \%$ \\
\hline & B & $26 / 32$ & 9,64 & 82,46 & 7,9 & 0,86 & 4,10 & 1,04 & 0,29 & 0,14 & 0,04 & 0,17 & 0,06 & 6,82 & 6,01 \\
\hline $\mathrm{CM}$ & $\mathrm{B}$ & $32 / 38$ & 10,49 & 80,80 & 8,71 & 0,31 & 4,25 & 0,94 & 0,21 & 0,12 & 0,04 & 0,15 & 0,05 & 5,92 & 6,08 \\
\hline & B2t & $44 / 52$ & 18,45 & 72,54 & 9,02 & 0,31 & 4,2 & 1,42 & 0,38 & 0,19 & 0,08 & 0,25 & 0,05 & 9,12 & 6,25 \\
\hline R & B & $10 / 20$ & 10,39 & 79,78 & 9,83 & 1,05 & 4,35 & 0,87 & 0,21 & 0,07 & 0,04 & 0,14 & 0,05 & 6,56 & 4,57 \\
\hline
\end{tabular}

Table 2: Comparative analytical data between the reference (P4) and the charcoal mound (P3) from the Zonien Forest (after Mees, 1989). HZ: Horizon, C\%: percentage of total carbone, $\mathrm{pH}$ : soil acidity, $\mathrm{FE} \%$ and $\mathrm{Al} \%$ : percentage of Iron and Aluminium (dithionite extraction), exch.bases: percentage of exchangeable bases (NH4OAc extraction), CEC: cation exchange capacity, expressed in meq/100g of soil, V\%: base saturation).

Tableau 2 : Données pédo-chimiques comparatives entre le sol de référence et la charbonnière de la forêt de Soigne (d'après Mees, 1989). HZ: Horizon, C\% : pourcentage de carbone total, $p H$ : acidité du sol, FE\% et AL\% : pourcentage de fer et d'aluminium (extraction à la dithionite), exch.bases : pourcentage de bases échangeables (extraction à $\mathrm{NH}_{4} \mathrm{Oac}$ ), CEC : capacité d'échange cationique en meq/100g, V\%: saturation en bases.

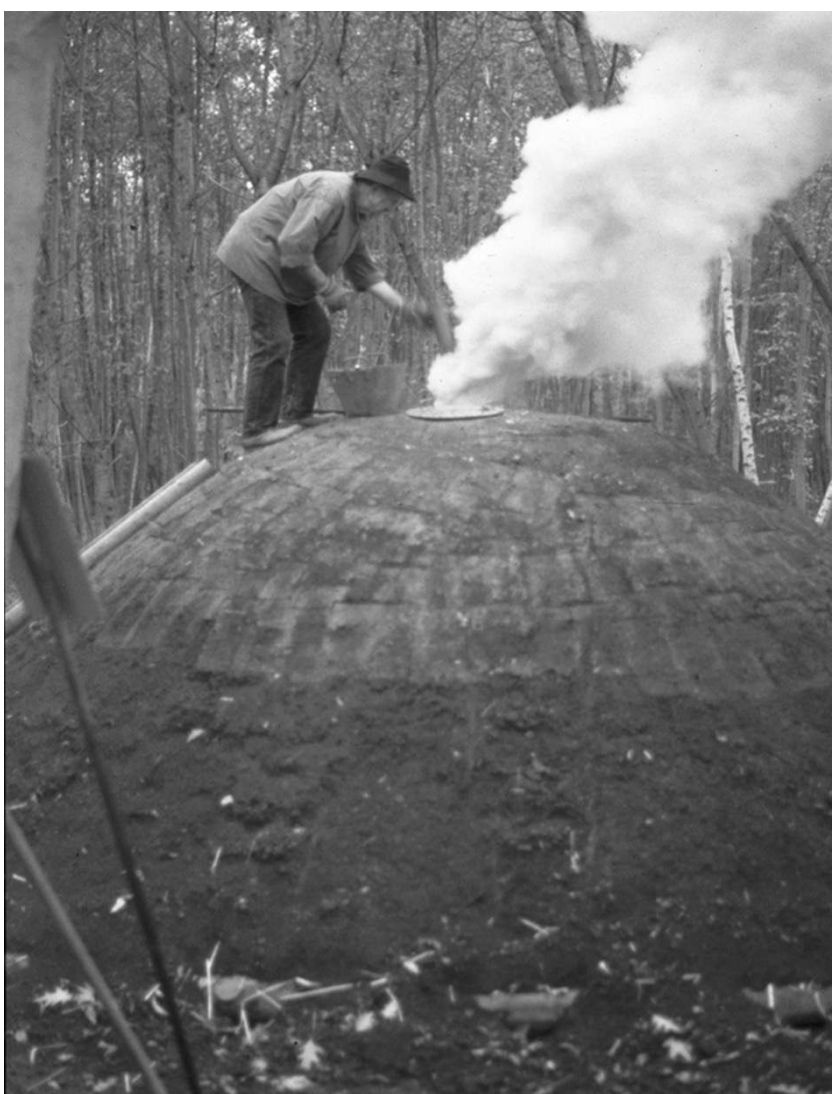

Figure 3: Through the chimney, from the top, wood and/or bad quality charcoal from the previous combustion is regularly added, and fresh pure clay is frequently added to cover the mound.

Figure 3: Du bois, ou du charbon de mavvaise qualité provenant des combustions précédentes, est apporté par la cheminée sommitale; de l'argile humide et pure est utilisée pour recouvrir la meule.

\section{Micromorphological modifications of soil profiles beneath charcoal burning sites}

At Paimpont forest (Fig. 4), the abandoned charcoal mound profile (P1) shows some differences compared with the undisturbed profile (P2). Although the porphyric fabric seems more or less similar, the structure is definitely more massive on the mound plot (P1). The latter is also characterized by the presence of amorphous organic matter, phytoliths, some diatoms and many burned/charred fragments such as charcoal (Plate e), melted glass-like droplets (Plate $\mathrm{g}, \mathrm{h}, \mathrm{i}$ ) and burned soil fragments (Plate j). The pedofeatures observed are dusty coatings and intercalations. In the undisturbed part of the plot, the horizon is very organic, showing a more intensive biological activity giving an increasingly pellety structure towards the top of the profile.

In the Zonien Forest, the sampling addressed the comparison of the natural $\mathrm{B}$ horizon and the position just under the black charcoal Ap horizon of the charcoal mound. Fig. 4 shows less difference between the reference profile and the charcoal mound than in the Paimpont forest case. We can note a little more charcoal and burned organic soilfragments, and an increase in dusty clay coatings and intercalations under the charcoal burning plot (Plate k). However, charcoal activities seem not to have affected the chemistry of the soils (Table 2, Mees, 1989).

At the Ecomusée de Haute Alsace case, we had the opportunity to compare a one time and a four times used charcoal burning plot to the reference forest soil (Fig. 4). The latter is very well structured, with an important pellety organic top A0/A1 horizon (Plate a). The soil profile on the only once used site seems quite compacted (Plate b) compared to the plot used four times (Plate c) that has a reworked and homogenised structure. In all these profiles appear iron concretions, which however derive from the alluvial sedi- 


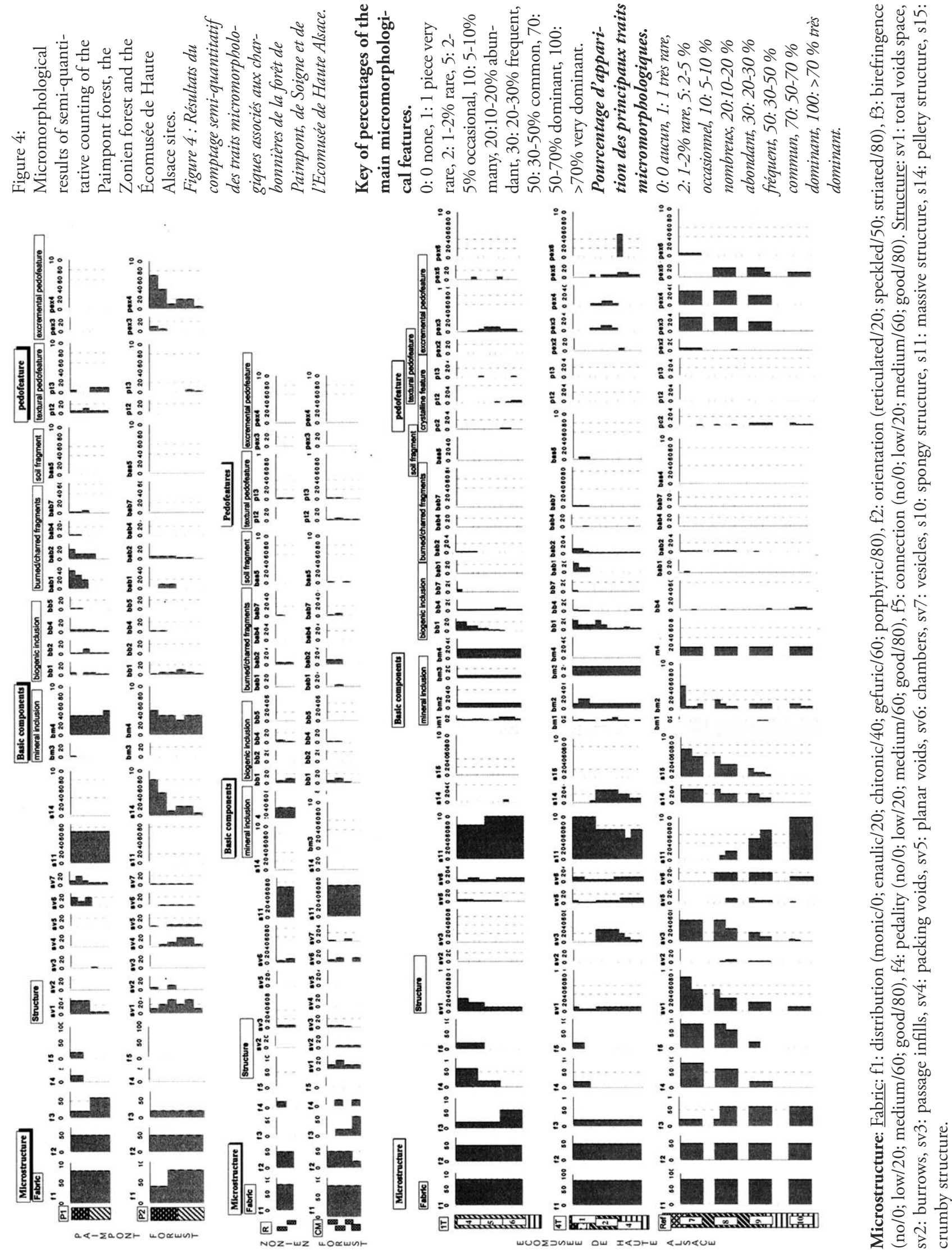


Microstructure: Fabrique: $f 1$ : distribution (moniquel0 ; énaulique/20; chitoniquel40; géfuriquel60; porphyrique/80), f2: orientation (réticulée/20; tachetéel50; striée/80), f3: biréfringence (aucunel0; faible/20; moyennel60; bonne/80), f4: pédalité (aucunel0; faiblel20; moyennel60; bonne/80), f5: connection (aucune/0; faible/20; moyenne/60; bonne/80). Structure: sv1:porosité totale, sv2: terrier pile d'assiettes, sv3: biogaleries, sv4: vides d'entassement, sv5: fissures, sv6: chambres, sv7: vésicules, s10: structure spongieuse, s11: structure massive, s14: structure pellety, s15: structure grumeleuse.

Basic components: Mineral inclusions: bm1: gravel-size flint, ironstone, quartz, chalk..., bm2: sand <1 mm, bm3: sand >1mm, bm4: loam. Biogenic inclusions: bb1: plant residues, bb2: amorphous organic matter, bb4: phytoliths, bb5: diatoms, bb7: spores/pollens. Anthropogenic inclusions: soil fragments: bas4: speckled calcitic soil fragments, bas5: reticulated clayey soil fragments; burned /charred fragments: bab1: coarse charcoal, bab2: fine charred plant remains, bab4: fused ash, bab7: burned soil fragments.

Composants majeurs: Inclusions minérales: bm1: silex, roche ferrugineuse, quartz, craie graveleuse..., bm2: sable <1mm, bm3: sable>1mm, bm4: limon. Inclusions biogénique: bb1: résidu de plantes, bb2: matière organique amorphe, bb4: phytolithes, bb5: diatomées, bb7: spores/pollens. Inclusions anthropiques: soil fragments de sol: bas4: fragments de sol calcitique tacheté, bas5: fragments de sol argileux réticulé ; fragments de sol brûlélcarbonisé: bab1: gros charbons, bab2: résidus végétaux carbonisés fins, bab4: cendres fondues, bab7: fragments de sol brûlé.

Pedofeatures: Crystalline/Depletion: pc2: rounded iron concretion (PPL: black, OIL: red). Textural: pt2: dusty clay coating \& infillings, pt3: intercalation. Excremental: pex2: mite pellets type, pex3: enchitraeïde pellet type, pex4: organo-mineral $(<100 \mu \mathrm{m})$, pex5: organicmineral $(100-500 \mu \mathrm{m})$, pex6: organic mineral $(>500 \mu \mathrm{m})$.

Traits pédologiques: Cristallisation/dissolution : pc2 : concrétion de fer arrondies (PPL : noir, OIL : rouge). Traits texturaux : pt $2:$ revêtements argileux poussiéreux \& remplissages, pt3 : intercalation. Formes excrémentales : pex2: déjections de type mite, pex3 : déjections de type enchi-

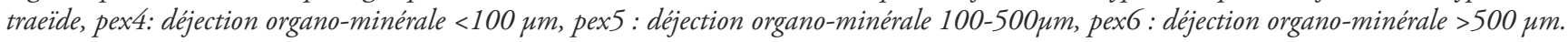

ments of the plots. Biogenic inclusions such as phytoliths, plant residues and spores/pollen are observable in all three profiles, with a little higher abundance in the profile used only once. Charred organic and soil fragments are more abundant under the four times used plot (Plate d). Dusty coatings and intercalations are less numerous than in the former Paimpont and Zonien Forest cases. Melted glass-like droplets appear in the profile of the 4 times used site.

To understand better the variation of texture, structure and colour due to the burning, 4 horizons (E1, E3, B2t, BC2) of a silt-loamy soil from the Zonien Forest (Belgium) were experimentally heated at $200^{\circ} \mathrm{C}, 400^{\circ} \mathrm{C}$ and $600^{\circ} \mathrm{C}$ (Table 3). Contrarily to the experiment from Mathieu and Stoops (1972), our results showed no differences in the macro/micro texture and structure of any horizon at any temperature. The only difference observed is a slight increase in intensity of reddish colour, visible only above $400^{\circ} \mathrm{C}$. This reddish colour change is more intense in the deeper horizons, as these have a slightly higher iron content. This characteristic is related to the higher clay content and the presence of clay coatings in the B horizon. The clay in these soils has indeed a brown colour as some iron ions, with a positive charge, are adsorbed on the negatively charged clay surfaces. This conclusion about the change in colour is the same as in the Mathieu and Stoops experiment (1972). Those authors pointed out that the iron hydrates are transformed to hematite at $800 / 1100^{\circ} \mathrm{C}$. No transformations of the quartz (melting) where noticed in either experiment.

\section{Discussion}

This study has pointed out some aspects of the impact of charcoal burning on the natural soil. Regarding the charcoal burning process, this influence is not so much due to the heating of the soil but more to the preparation of the working area and the construction of the mound. The colour of the soil under a charcoal mound is not a good indicator of charcoal making, unless the wooden stack burnt out because of inattention of the charcoal burner. The fragments

\begin{tabular}{|l|l|l|l|l|}
\hline & Unburned & $200^{\circ} \mathrm{C}$ & $400^{\circ} \mathrm{C}$ & $600^{\circ} \mathrm{C}$ \\
\hline $\mathrm{E}_{1}$ & $\begin{array}{l}10 \mathrm{YR} 7 / 3 \\
\text { dull yellow orange }\end{array}$ & $\begin{array}{l}10 \mathrm{YR} 6 / 3 \\
\text { dull yellow orange }\end{array}$ & $\begin{array}{l}7,5 \mathrm{YR} 7 / 4 \\
\text { dull orange }\end{array}$ & $\begin{array}{l}5 \mathrm{YR} 7 / 4 \\
\text { dull orange }\end{array}$ \\
\hline $\mathrm{E}_{3}$ & $\begin{array}{l}10 \mathrm{YR} 7 / 2 \\
\text { dull yellow orange }\end{array}$ & $\begin{array}{l}10 \mathrm{YR} 6 / 4 \\
\text { dull yellow orange }\end{array}$ & $\begin{array}{l}7,5 \mathrm{YR} 6 / 6 \\
\text { orange }\end{array}$ & $\begin{array}{l}5 \mathrm{YR} 6 / 6 \\
\text { orange }\end{array}$ \\
\hline $\mathrm{B}_{\mathrm{t}}$ & $\begin{array}{l}10 \mathrm{YR} 7 / 4 \\
\text { dull yellow orange }\end{array}$ & $\begin{array}{l}\text { 10YR } 6 / 4 \\
\text { dull yellow orange }\end{array}$ & $\begin{array}{l}5,5 \mathrm{YR} 7 / 6 \\
\text { orange }\end{array}$ & $\begin{array}{l}5 / 8 \\
\text { bright reddish brown }\end{array}$ \\
\hline $\mathrm{BC}_{2}$ & $\begin{array}{l}\text { 10YR } 7 / 6 \\
\text { bright yellowish brown }\end{array}$ & $\begin{array}{l}10 \mathrm{YR} 6 / 6 \\
\text { bright yellowish brown }\end{array}$ & $\begin{array}{l}7,5 \mathrm{YR} 5 / 6 \\
\text { bright brown }\end{array}$ & $\begin{array}{l}5 \mathrm{YR} 5 / 8 \\
\text { bright reddish brown }\end{array}$ \\
\hline
\end{tabular}

Table 3: Colour variation of the silt-loamy profile with depth and heating intensity; colour named after Oyama and Takehara (1967). Tableau 3: Variation de couleur des horizons de sol limon-silteux en fonction de la profondeur et de l'intesité de combustion; couleur d'après OYAM and Takehara (1967). 


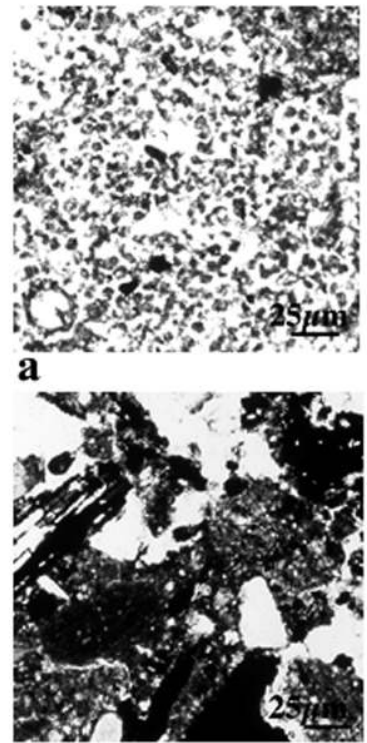

d

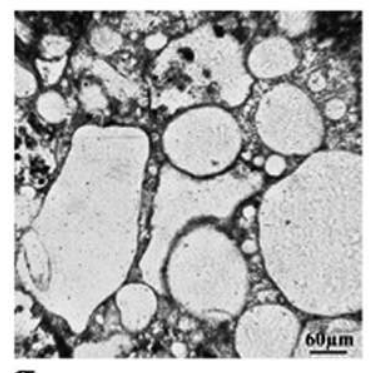

g

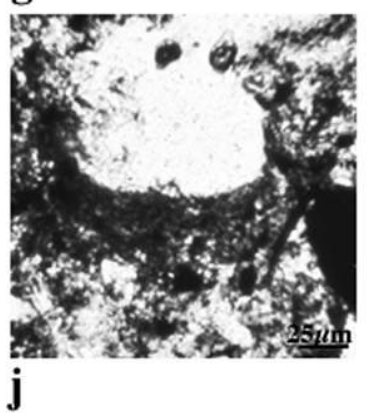

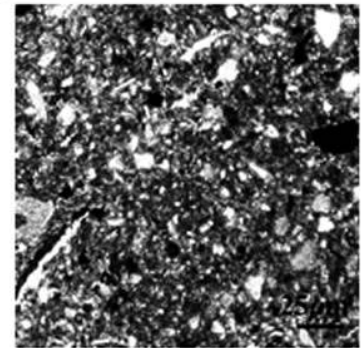
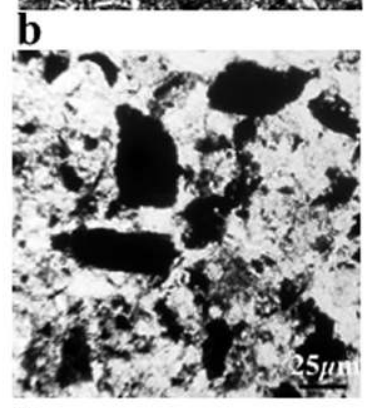

e

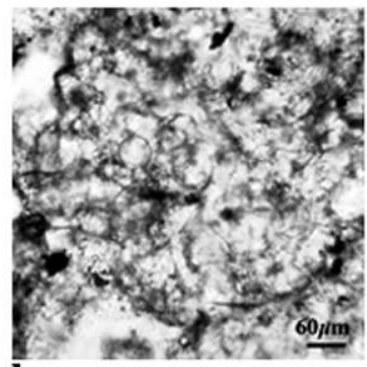

h

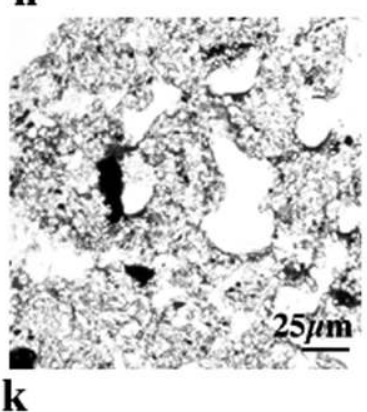

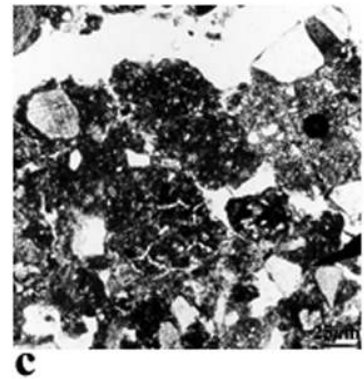

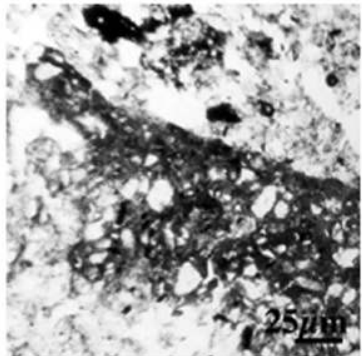

\section{f}
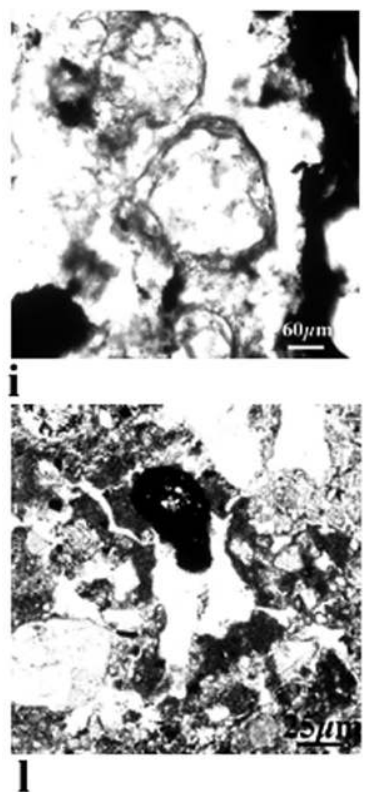

Plate 1

Planche 1

a. Very well structured undisturbed natural soil, with an important pellety organic top A0/A1 horizon (Ecomusée de Haute Alsace).

Sol naturel non perturbé très bien structuré, avec un horizon sommital organique A0/AI (Ecomusée de Haute Alsace).

b. Moderately compact structure from the soil profile used only one time (Ecomusée de Haute Alsace).

Structure moyennement compacte du sols sous charbonnière utilisée une fois (Écomusée de Haute-Alsace).

c. Reworked and homogenised structure caused by finely mixing and sifting of earth after each of the 4 operations (Ecomusée d'Alsace).

Structure perturbée et homogène, liée au mélange et tamisage de la terre après chacune des quatre utilisations de l'aire de la meule (Écomusée de Haute-Alsace).

d./e. Abundant charred organic fragments at Paimpont Forest (e) and under the four times used plot from the Ecomusée de Haute Alsace (d).

Abondants fragments organiques brûlés en forêt de Paimpont (e) et sous l'aire utilisée deux fois de l'Écomusée de Haute-Alsace (d).

f. Fragment of burned soil probably from the very finely crumby organo-mineral mixture covering the mound and that penetrates into the smallest holes when the stack settles during the burning (Paimpont Forest).

Fragments de sol brûlé argilo-organique, provenant probablement de la couverture sommitale finement fragmentés de la meule et ayant pénétré dans les trous entre les rondins de bois durant la combustion (Forêt de Paimpont).

g./h./i.: Melted glass-like droplet resulting from high temperature phytolith combustion in nearby open air fires besides the wood stack, (Paimpont Forest).

Phytolithe fondu provenant probablement de la combustion de graminées dans des foyers domestiques des charbonniers (Forêt de Paimpont). j./k./l.: Different kinds of dusty clay coatings associated with charcoal burning activity due to the combination of deforestation and strong preparation of the soil surface (levelling, digging) from the Paimpont Forest (j), the Zonien Forest (k.) and from the four times used profile from the Ecomusée de Haute Alsace (1.). In the last site some intercalations are also developed.

Différents revêtements argileux poussiéreux générés par la déforestation et la préparation des aires de charbonnage (labour, nivellement) en forêt de Paimpont (j), forêt de Soigne (k) et de la charbonnière utilisée 4 fois à l'Écomusée de Haute-Alsace (1). Dans de dernier site, on observe également des intercalations. 
of burned soil observed should than be interpreted as clods of the very finely crumby organic-mineral mixture covering the mound in order to slow down the combustion temperature.

The main difference is the increase, in the upper part of the profiles, of more or less charred plants and burned soil fragments. In the case of plots used several times (Paimpont Forest, Ecomusée d'Alsace) thin sections showed finely mixed earth and charcoal which result from the mixing/ homogenisation and sifting of the sediment after each use.

The melted glass-like droplets observed in some cases (Paimpont, Ecomusée), are very similar to the ones often described in open air archaeological site sediments and interpreted as melted opal phytoliths (Gebhardt and Langohr, $1999)$. As the melting temperature of the quartz $\left(800^{\circ} \mathrm{C}\right.$, Mathieu and Stoops, 1972) is not supposed to be reached in the centre of the stack, those features probably come from nearby open fires used for the lighting process of the wood stack or any other temporary domestic activity of the charcoal burner such as heating and cooking. The phytoliths observed in many cases are imported with the pieces of turves coming from nearby pool banks (Paimpont forest), used to cover the charcoal mound. Diatoms probably have the same origin.

Dusty clay coatings seem to be commonly associated with charcoal burning activities. Usually those features are explained by the splash effect of the rain on a bare surface, most often cultivated (Jongerius, 1983). In a forest context, charcoal-burning activity is a good explanation of those features. The combination of the local deforestation and the rigorous preparation of the soil surface (levelling, digging, trampling) necessary to this activity can generate a periodic long-term bare surface propitious to dusty clay coating and intercalation formation.

\section{Conclusions}

This micromorphological study of several soil profiles located under ancient archaeological and recent analogous charcoal production sites, completed by some laboratory soil heating experiments, helps to understand better the impact of charcoal production activities on soils.

Contrary to some common ideas, the impact of charcoal production on the soil morphology is not directly due to the heating effects of wood carbonisation but more to the preparation and the management of the plots before, during and after the production phase. Traces are detected of the clearing of the soil and of the type of earth used to cover the mound. It appears that latter material can come from somewhat distant plots as preference is given to turves with well-developed grass vegetation. The observation of phytoliths and diatoms in the soil thin sections is a useful tool in this aspect of the research. Other traces, such as melted phytoliths and some baked earth fragments appear to belong either to the domestic activities of the charcoal burners and to the charcoal production itself.

The perception of the influence of charcoal activities on the soil chemistry and vegetation remains unexplored, but this paper could be the start for more investigations.

\section{Acknowledgements}

This work is a small personal unfunded project whose aim was to understand better the effects of charcoal exploitation on the soil micromorphology. I would like to thank all the collegues who kindly allowed me to sample on archaeologi$\mathrm{cal} /$ experimental sites and use their field data. They are:

M. Grodwohl director of the Ecomusée de Haute Alsace (France) and M. Grosz the charcoal-burner who conducted the experimental part of this work, J.-Y. Hunot who studied the Paimpont forest (France) ancient charcoal mound and allowed me to use his field observations, and R. Langohr from the Laboratory of Pedology of Gent (Belgium) who allowed me to use data from the Zonien Forest collected by his doctorant F. Mees.

I also thank the Laboratory of micropedology of Gent (Belgium) directed by Prof. Stoops, for the production of the thin sections and the help in the heating experiment of soil samples. I won't forget the useful discussions with R. I. Macphail (Institute of Archaeology, London) and S. Limbrey (Birmingham University), with a special thanks to the latter for the help to improve the English text.

\section{References}

Bouflet, B. and Lebreton, M., 1994. Les chaffras du Maine. Forêts, l'or vert du Maine, Maine découverte, 2 : 47-49.

Bullock, P., Fedoroff, N., Jongerius, A., Stoops, G., Tursina, T. and BABEL, U., 1985. Handbook for soil thin section description, Wolverhampton, United Kingdom : Waine Research.

Gebhardt, A., Marguerie, D. and Hunot, J.-Y., 1995. Meules de charbonnier et archéométrie : problématique, méthodologie et premiers résultats. In L'archéométrie dans les pays Européens 
de langue latine, Colloque d'archéométrie de Périgueux 26/29 avril 1995, GMPCA, p. 119.

GebHaRdT, A. and LANGohr, R., 1999. Micromorphological study of construction material and living floors in the Medieval motte of Werken (West Flanders, Belgium). Geoarcheology : An International Journal, $14: 7$ : 595-620.

HunOt, J.-Y., 1993. Sondages dans la charbonnière, Université de Rennes, Unpublished field notes.

Jongerius, A., 1983. The role of micromorphology in agricultural research. In P. Bullock (Ed.) Soil micromorphology, 111-138.
LARCHER, G., 1986. Les charbonniers à Paimpont. Contribution à l'histoire d'une commune, Le Chatenay : Numéro Hors Série.

Mathieu, C. and Stoops, G., 1972. Observations pétrographiques sur la paroi d'un four à chaux carolingien creusé en sol limoneux. Archéologie Médiévale, II : 347-354.

MeEs, F., 1989. Base maps and soil survey of undistrubed iron industry sites in the Zonien Forest (Loess Belt, Belgium), Master theses, International Training Center for Soil Scientists, Université de Gand, Belgique.

Oyama, M. and Takehara, H., 1967. Revised Standard Soil Color Chart. 